\title{
Carbonyl compounds in boreal coniferous forest air in Hyytiälä, Southern Finland
}

\author{
H. Hellén ${ }^{1}$, H. Hakola ${ }^{1}$, A. Reissell ${ }^{2,3}$, and T. M. Ruuskanen ${ }^{2}$ \\ ${ }^{1}$ Finnish Meteorological Institute, Sahaajankatu 20 E, 00880 Helsinki, Finland \\ ${ }^{2}$ University of Helsinki, Department of Physical Sciences, Finland \\ ${ }^{3}$ University of Helsinki, Department of Chemistry, Finland
}

Received: 16 April 2004 - Published in Atmos. Chem. Phys. Discuss.: 3 June 2004

Revised: 26 August 2004 - Accepted: 26 August 2004 - Published: 8 September 2004

\begin{abstract}
A variety of $\mathrm{C}_{1}-\mathrm{C}_{12}$ carbonyl compounds were measured in the air of a boreal coniferous forest located in Hyytiälä, Southern Finland. 24-hour samples were collected during March and April in 2003 using DNPH (2,4dinitrophenyl hydrazine) coated $\mathrm{C}_{18}$-cartridges and analyzed by liquid chromatography-mass spectrometry (LC-MS).

Altogether 22 carbonyl compounds were quantified. The most abundant carbonyls were acetone (24-hour average $\left.1340 \mathrm{ng} / \mathrm{m}^{3}\right)$, formaldehyde $\left(480 \mathrm{ng} / \mathrm{m}^{3}\right)$ and acetaldehyde $\left(360 \mathrm{ng} / \mathrm{m}^{3}\right)$. Concentrations of monoterpene reaction products nopinone $\left(9 \mathrm{ng} / \mathrm{m}^{3}\right)$ and limona ketone $\left(5 \mathrm{ng} / \mathrm{m}^{3}\right)$ were low compared to the most abundant low molecular weight carbonyls. Trajectory analysis showed that highest concentrations of carbonyls were measured in the air masses coming from the East and the lowest in the air masses cycled long time over Scandinavia. The total concentration of carbonyl compounds in Hyytiälä in March/April 2003 was much higher than the concentration of aromatic hydrocarbons and monoterpenes in April 2002.
\end{abstract}

Scaling the concentrations against reactivity with the $\mathrm{OH}-$ radical showed, that in spite of relatively low ambient concentrations higher molecular weight aldehydes contribute significantly to the total $\mathrm{OH}$-reactive mass of carbonyls. The impact of carbonyl compounds on OH-radical chemistry is important. Contribution of carbonyls as an $\mathrm{OH}$ sink is comparable to that of $\mathrm{NO}_{2}$ and higher than monoterpenes and aromatic hydrocarbons.

Lifetimes of the measured carbonyls with respect to reactions with $\mathrm{OH}$ radicals, ozone $\left(\mathrm{O}_{3}\right)$, and nitrate $\left(\mathrm{NO}_{3}\right)$ radicals as well as photolysis were estimated. The main sink reactions for most of the carbonyl compounds in Hyytiälä in springtime are expected to be reactions with the $\mathrm{OH}$ radical and photolysis. For 6-methyl-5-hepten-2-one and limona ketone also reactions with ozone are important. The sources of

Correspondence to: H. Hellén

(heidi.hellen@fmi.fi) carbonyl compounds are presently highly uncertain. Based on the comparisons with urban concentrations the direct anthropogenic emissions are not as important as secondary biogenic and anthropogenic sources or primary biogenic sources in Hyytiälä.

\section{Introduction}

Carbonyl compounds (aldehydes and ketones) are a class of organic compounds that have both primary and secondary anthropogenic and biogenic sources. These sources are not well known, but anthropogenic sources include at least car exhaust emissions, wood combustion and solvent evaporation (Friedrich and Obermeier, 1999). Some coniferous trees (Pinus sylvestris and Picea abies) have been shown to emit significant amounts of acetone and acetaldehyde (Janson et al., 2001) and agricultural species (Arey et al., 1991; Köning et al., 1995) as well as stressed plants (Hakola et al., 2001) have been found to emit $\mathrm{C}_{6}$ carbonyl compounds. Also other carbonyl compounds can be emitted from plants, but these emission rates are poorly known (Fall, 1999). In addition to the direct emissions, carbonyls are formed in the atmosphere from the oxidation of other volatile organic compounds.

Carbonyls can comprise a substantial proportion of total volatile organic compounds in the atmosphere (Fehsenfeld et al., 1992) and they play an important role in photochemical reactions. Aldehydes and ketones undergo photolysis and react with hydroxyl $(\mathrm{OH})$ radicals and nitrate $\left(\mathrm{NO}_{3}\right)$ radicals (Atkinson, 2000). Carbonyls and their reaction products participate in formation of ozone and peroxyacetyl nitrate (PAN). Some of the higher molecular weight carbonyls are semivolatile and their contribution to new particle formation may be substantial (Matsunaga et al., 2004). Since some carbonyls (e.g. formaldehyde) are water soluble, significant concentrations have been measured in fogs and clouds (Grosjean and Wright, 1983). In aerosol particles carbonyls may 

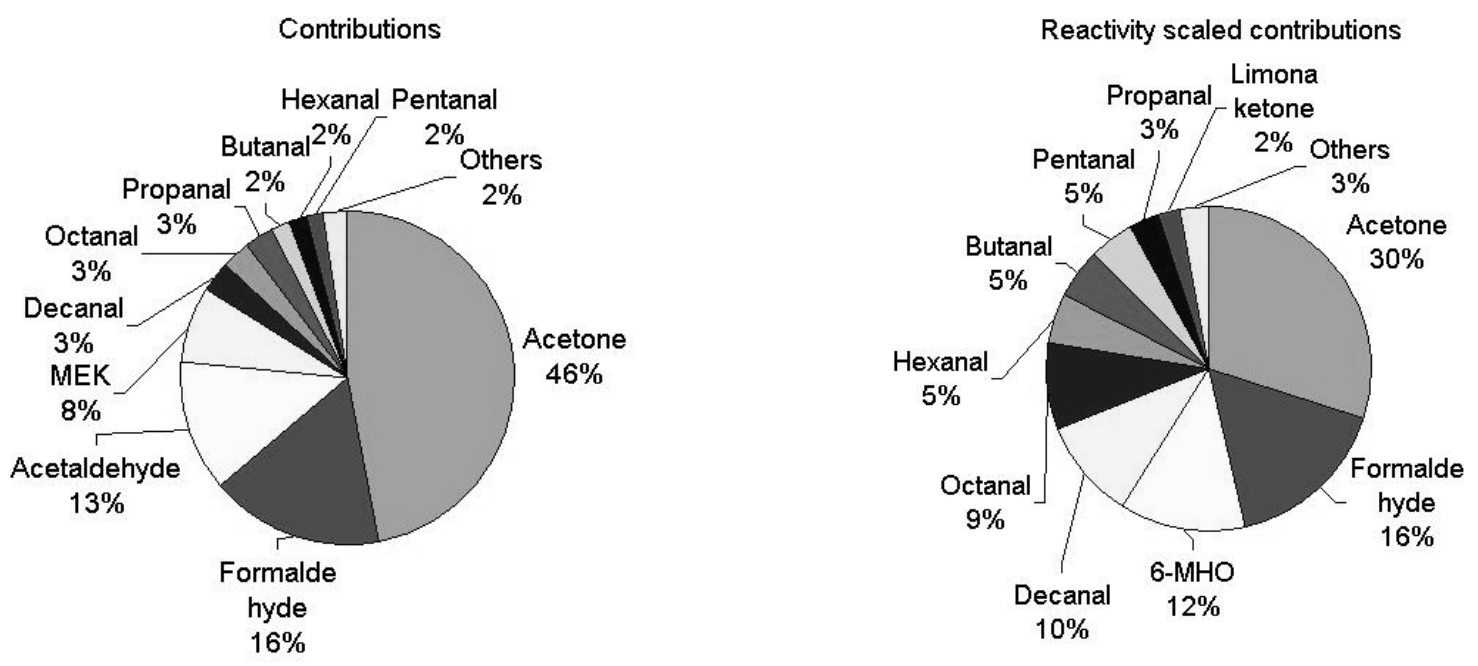

Fig. 1. Average contributions of the individual carbonyl compounds to the total average concentration and to the average reactivity scaled concentration.

also act as surfactants (Finlayson-Pitts and Pitts, 2000) hence changing their surface properties. Long-chained carbonyls $\left(\geq C_{5}\right)$ may form surface films on droplets by lining up with the polar ends in the water and nonpolar, hydrophobic ends projecting into air. Photolysis of aldehydes can be a major source of hydroxyl radicals during the day (Possanzini et al., 2002). Some of the carbonyls are also known to have toxic and carcinogenic properties.

While some light carbonyls, such as formaldehyde, acetone and acetaldehyde, have been studied quite intensively, there are only a few studies on larger aldehydes and ketones. In this paper we report atmospheric concentrations for 22 different $\mathrm{C}_{1}-\mathrm{C}_{12}$ carbonyl compounds measured in a boreal coniferous forest located in Hyytiälä, Finland. Measurements were conducted in March and April 2003 during QUEST II (Quantification of Aerosol Nucleation in the European Boundary Layer) campaign.

\section{Experimental}

\subsection{Site description}

Measurements took place at the SMEAR (Station For Measuring Forest Ecosystem-Atmosphere Relations, $61^{\circ} 51^{\prime} \mathrm{N}$, $24^{\circ} 17^{\prime} \mathrm{E}, 181 \mathrm{~m}$ a.s.l.) II station located in Hyytiälä, Central Finland. The surroundings are mainly forest with some fields and few houses. Distance to the closest town Tampere with 201000 inhabitants is $40 \mathrm{~km}$. The forest around the station is dominated by conifers (mainly Scots pine but also Norway spruce) with some deciduous trees, such as aspen and birch. Fifteen minute averages of the temperature varied between -11.1 and $8.6^{\circ} \mathrm{C}$ during the measurement period. The site is described in more detail by Vesala et al. (1998).

\subsection{Sampling and analysis}

Sampling equipment was placed inside the forest with sampling inlet height at one meter above ground level. Samples were collected by drawing air through $\mathrm{C}_{18}$-cartridges (Sep-Pak, Waters) coated with DNPH (2,4-dinitrophenyl hydrazine). An ozone scrubber (copper tubing coated with potassium iodide) was placed in front of the sampling cartridges. Flow rate was $976 \mathrm{ml} / \mathrm{min}$ and the sampling time was about $24 \mathrm{~h}$.

Between 19 March and 13 April, 25 diurnal samples were collected. The carbonyl compounds were derivatized in cartridges to (2,4-dinitrophenyl)hydrazones during sampling. In the laboratory, the cartridges were eluted with $3 \mathrm{ml}$ of acetonitrile and the eluants were analysed using a liquid chromatograph equipped with a XDB C-8 column (length $150 \mathrm{~mm}$, i.d. $4.6 \mathrm{~mm}$ ) and a mass spectrometer with negative atmospheric pressure chemical ionization (Agilent 1100 Series LC/MSD trap). Water buffered with $1 \mathrm{M}$ ammonium acetate $\left(1 \mathrm{ml} / 1 \mathrm{~L} \mathrm{H}_{2} \mathrm{O}\right)$ and acetonitrile were used in gradient elution. The analysis method was adapted from Grosjean et al. (1999).

DNPH-derivates of undecanal, heptanal, nonanal, trans-2hexenal, laurinaldehyde, decanal, 6-methyl-5-hepten-2-one (6-MHO), nopinone, octanal and limona ketone were prepared according to instructions from the manual for sampling and analysis of the co-operative programme for monitoring and evaluation of the long-range transmissions of air pollutants in Europe (EMEP, 1996). For hexanal, formaldehyde, methyl ethyl ketone (MEK), butanal, pentanal, propanal, acetaldehyde, acetone, acrolein, benzaldehyde, 2-butenal, mtolualdehyde and methacrolein commercial liquid DNPHcarbonyl standard in acetonitrile (Carb Method 1004 DNPH Mix 2, Supelco) was used. 


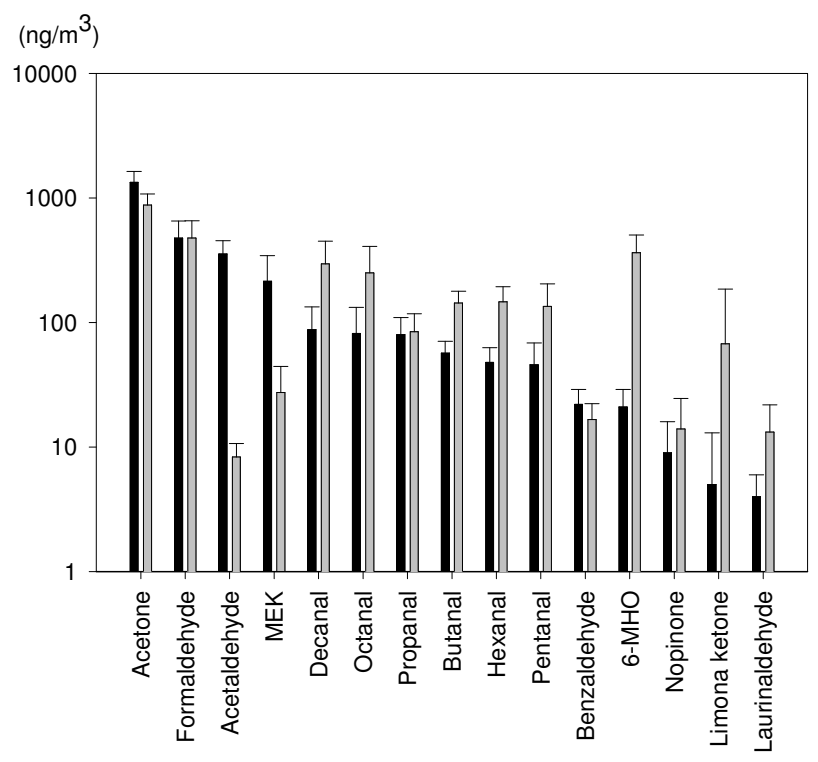

Fig. 2. Average 24-h concentrations of carbonyl compounds (black bars) and average OH-reactivity scaled concentrations $\left(C_{e q v}\right.$, as formaldehyde equivalents) (grey bars) in ambient air at Hyytilälä and standard deviations between the samples shown as error bars, 19 March-13 April, 2003.

Detection limits were defined either as three times the standard deviation of six blank samples or for the compounds with zero blank value from the signal-to-noise ratio 10:1 Detection limits varied from $1 \mathrm{ng} / \mathrm{m}^{3}$ to $135 \mathrm{ng} / \mathrm{m}^{3}$ (Table 2). Efficiency of the DNPH cartridges was tested by using a back up cartridge after a sampling cartridge. Sampling effiency for the lightest compounds, formaldehyde, acetaldehyde and acetone, was $93 \%, 99 \%$ and $83 \%$, respectively.

\section{Results and discussion}

\subsection{Ambient concentrations of carbonyl compounds}

Acetone, formaldehyde and acetaldehyde were the most abundant carbonyls in Hyytiälä in March/April 2003 contributing to $75 \%$ of all measured carbonyls by mass (Fig. 1). Average 24-h concentrations of acetone, formaldehyde and acetaldehyde were 1340,480 and $360 \mathrm{ng} / \mathrm{m}^{3}$, respectively (Fig. 2 and Table 2). These concentrations were at the same level as in several rural European sites in March/April 19931995 (Solberg et al., 1996). For example acetone, formaldehyde and acetaldehyde concentrations were 1810, 536 and $445 \mathrm{ng} / \mathrm{m}^{3}$ in Birkenes, Norway $\left(58^{\circ} 23^{\prime} \mathrm{N}, 8^{\circ} 15^{\prime} \mathrm{E}\right)$ and 2899,861 and $716 \mathrm{ng} / \mathrm{m}^{3}$ in Waldhof, Germany $\left(52^{\circ} 48^{\prime} \mathrm{N}\right.$, $9^{\circ} 30^{\prime} \mathrm{E}$ ). Ambient air concentration data for the other aldehydes and ketones is scarce. There are some measurements from Rome (Ciccioli et al., 1997), Los Angeles (Grosjean et al., 1996) and Rio de Janeiro (Grosjean et al., 2002) reported.

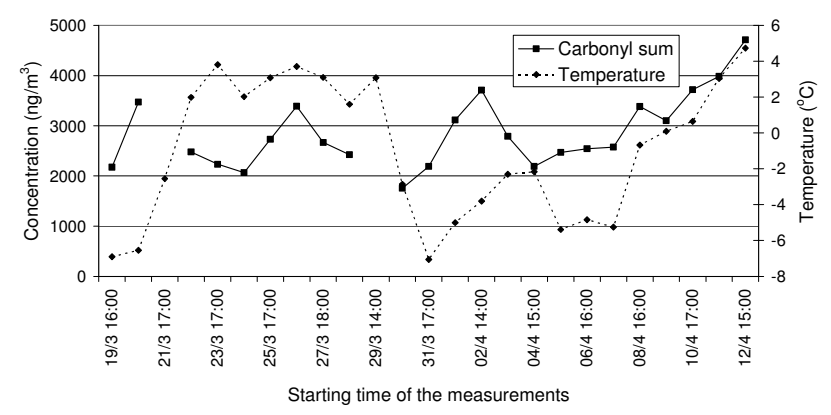

Fig. 3. Daily variation of carbonyl compounds in ambient air at Hyytilälä, 19 March-13 April, 2003, based on 24-h samples.

Generally concentrations of $\mathrm{C}_{3}-\mathrm{C}_{10}$ aldehydes in those cities are much higher than in Hyytiälä e.g. in Los Angeles in September 1993 concentrations were 24 to 46 times higher. There are also some rural measurements of $\mathrm{C}_{4}-\mathrm{C}_{10}$ carbonyls from Italy for September 1990 and 1992 (Ciccioli et al., 1997) and some measurements from remote sites in Japan from May 1987 and 1988 (Yokouchi et al., 1990), but also in those studies the concentrations are several times higher than in this study. In Hyytiälä in March/April 2003 average 24-h concentrations of $\mathrm{C}_{3}-\mathrm{C}_{10}$ aldehydes were between 46 and $88 \mathrm{ng} / \mathrm{m}^{3}$. In summer concentrations can be higher also in Hyytiälä. At least for the acetone, acetaldehyde and formaldehyde higher concentrations have been measured during summer than in winter or spring in rural areas of northern and middle parts of Europe (Solberg et al., 1996).

Average concentrations of nopinone and limona ketone, reaction products of monoterpenes $\beta$-pinene and limonene, were low $\left(9 \mathrm{ng} / \mathrm{m}^{3}\right.$ and $\left.5 \mathrm{ng} / \mathrm{m}^{3}\right)$ compared to the most abundant light carbonyl compounds. This is expected since also the monoterpene concentrations are low during early spring (Hakola et al., 2003). $\alpha$-Pinene is the most common monoterpene in ambient air in Hyytiälä, but no standard for the main $\alpha$-pinene oxidation product, pinonaldehyde, was available and therefore pinonaldehyde was not measured. The concentrations of acrolein, 2-butenal, trans-2-hexenal, methacrolein, undecanal, m-tolualdehyde, nonanal and heptanal remained mostly below the detection limit during the measurement period.

Daily variation of the sum of the 24-hour averages of carbonyl concentrations and temperature is shown in Fig. 3. Average 24-h concentration of all measured carbonyls is $2850 \mathrm{ng} / \mathrm{m}^{3}$. Variation between days is quite high from 1760 to $4710 \mathrm{ng} / \mathrm{m}^{3}$. Correlation $\left(\mathrm{R}^{2}\right)$ of the total concentration of the carbonyls with the temperature was 0.09 and with photosynthetic active radiation (PAR) 0.07 . As will be discussed in the Sect. 3.5 the concentrations are different in different air masses and correlations are higher if different wind sectors are studied separately. For example in the air masses coming from the East (6 days out of 23) correlation with temperature was 0.52 and with PAR 0.49. This can also be seen from 
Table 1. Rate constants and calculated lifetimes of the carbonyl compounds measured in this study.

\begin{tabular}{|c|c|c|c|c|c|c|c|c|c|}
\hline & \multirow{2}{*}{$\begin{array}{l}\text { Photolysis rate } \\
\mathrm{K}_{p}{ }^{*} 10^{-5}\left(\mathrm{~s}^{-1}\right)\end{array}$} & \multicolumn{4}{|c|}{ Rate constants $\left(\mathrm{cm}^{3} / \mathrm{molec} / \mathrm{s}\right)$} & \multicolumn{4}{|c|}{ Lifetime $^{A}$ due to } \\
\hline & & $\mathrm{k}(\mathrm{OH})_{L}$ & $\mathrm{k}(\mathrm{OH})_{s}$ & $\mathrm{~K}\left(\mathrm{O}_{3}\right)$ & $\mathrm{k}\left(\mathrm{NO}_{3}\right)$ & Photolysis $B$ & $\mathrm{OH}^{C}$ & $\mathrm{O}_{3} D$ & $\mathrm{NO}_{3} E$ \\
\hline Formaldehyde & $3.563^{v}$ & $9.38 \mathrm{E}-12^{a}$ & & $2.09 \mathrm{E}-24^{b}$ & $5.60 \mathrm{E}-16^{a}$ & $8 \mathrm{~h}$ & $2.6 \mathrm{~d}$ & $15000 \mathrm{a}$ & $317 \mathrm{~d}$ \\
\hline Acetaldehyde & $0.142^{v, w}$ & $6.15 \mathrm{E}-12^{a}$ & & $5.99 \mathrm{E}-21^{c}$ & $2.72 \mathrm{E}-15^{a}$ & $8.1 \mathrm{~d}$ & $3.6 \mathrm{~d}$ & $5.4 \mathrm{a}$ & $65 \mathrm{~d}$ \\
\hline Propanal & $0.484^{v, w, x}$ & $9.98 \mathrm{E}-12^{a}$ & & & $6.50 \mathrm{E}-15^{a}$ & $2.4 \mathrm{~d}$ & $2.2 \mathrm{~d}$ & & $27 \mathrm{~d}$ \\
\hline Butanal & $0.723^{v, w, y}$ & $2.38 \mathrm{E}-11^{d}$ & $2.29 \mathrm{E}-11$ & & $1.11 \mathrm{E}-14^{a}$ & $1.6 \mathrm{~d}$ & $22 \mathrm{~h}$ & & $16 \mathrm{~d}$ \\
\hline Pentanal & $0.746^{v, y}$ & $2.76 \mathrm{E}-11^{e}$ & $2.43 \mathrm{E}-11$ & & $1.81 \mathrm{E}-14^{f}$ & $1.5 \mathrm{~d}$ & $19 \mathrm{~h}$ & & $9.8 \mathrm{~d}$ \\
\hline Hexanal & $0.884^{v, y, z}$ & $2.86 \mathrm{E}-11^{d}$ & $2.57 \mathrm{E}-11$ & & $2.37 \mathrm{E}-14^{f}$ & $1.3 \mathrm{~d}$ & $18 \mathrm{~h}$ & & $7.5 \mathrm{~d}$ \\
\hline Heptanal & & $2.96 \mathrm{E}-11^{g}$ & $2.71 \mathrm{E}-11$ & & $2.43 \mathrm{E}-14^{f}$ & & $18 \mathrm{~h}$ & & $7.3 \mathrm{~d}$ \\
\hline Octanal & & & $2.86 \mathrm{E}-11$ & & & & $19 \mathrm{~h}$ & & \\
\hline Nonanal & & $3.60 \mathrm{E}-11^{h}$ & $3.00 \mathrm{E}-11$ & & & $\sim 1.6 \mathrm{~d}$ & $15 \mathrm{~h}$ & & \\
\hline Decanal & & & $3.14 \mathrm{E}-11$ & & & & $17 \mathrm{~h}$ & & \\
\hline Undecanal & & & $3.28 \mathrm{E}-11$ & & & & $16 \mathrm{~h}$ & & \\
\hline Laurinaldehyde & & & $3.42 \mathrm{E}-11$ & & & & $15 \mathrm{~h}$ & & \\
\hline MEK & $0.397 / 0.0397^{F, v, w}$ & $1.20 \mathrm{E}-12^{a}$ & & & & $2.9 / 29 \mathrm{~d}$ & $18 \mathrm{~d}$ & & \\
\hline Acetone & $0.021^{v, w}$ & $2.19 \mathrm{E}-13^{i}$ & & & $3.00 \mathrm{E}-17^{a}$ & $56 \mathrm{~d}$ & $100 \mathrm{~d}$ & & $16 \mathrm{a}$ \\
\hline Nopinone & & $1.43 \mathrm{E}-11^{j}$ & & & & $>8 \mathrm{~d}$ & $1.5 \mathrm{~d}$ & & \\
\hline trans-2-hexenal & & $4.40 \mathrm{E}-11^{k}$ & & $1.28 \mathrm{E}-18^{l}$ & $1.21 \mathrm{E}-14^{k}$ & & $12 \mathrm{~h}$ & $9.1 \mathrm{~d}$ & $15 \mathrm{~d}$ \\
\hline Limona ketone & & $1.29 \mathrm{E}-10^{j}$ & & $1.50 \mathrm{E}-16^{j}$ & $1.05 \mathrm{E}-11^{j}$ & $>8 \mathrm{~d}$ & $4 \mathrm{~h}$ & $2 \mathrm{~h}$ & $24 \min$ \\
\hline 6-MHO & & $1.60 \mathrm{E}-10^{m}$ & & $3.94 \mathrm{E}-16^{l}$ & & & $3.3 \mathrm{~h}$ & $42 \min$ & \\
\hline Methacrolein & $0.094^{v, y, z}$ & $2.76 \mathrm{E}-11^{n}$ & & $1.30 \mathrm{E}-18^{\circ}$ & $3.30 \mathrm{E}-15^{p}$ & $12 \mathrm{~d}$ & $19 \mathrm{~h}$ & $8.9 \mathrm{~d}$ & $54 \mathrm{~d}$ \\
\hline Benzaldehyde & & $7.09 \mathrm{E}-12^{q}$ & & & $2.01 \mathrm{E}-15^{r}$ & & $3.1 \mathrm{~d}$ & & $88 \mathrm{~d}$ \\
\hline 2-butenal & & $2.81 \mathrm{E}-11^{s}$ & & $1.74 \mathrm{E}-18^{t}$ & $5.11 \mathrm{E}-15^{u}$ & $\sim 1.6 \mathrm{~d}$ & $19 \mathrm{~h}$ & $6.7 \mathrm{~d}$ & $35 \mathrm{~d}$ \\
\hline
\end{tabular}

$L$ value from literature

${ }^{S}$ Structure-reactivity relationship calculated value

${ }^{A}$ An atmospheric lifetime is defined as the time required for the compound concentration value to degrade to a value of $1 / \mathrm{e}$ of its initial concentration.

${ }^{B}$ Photolysis rates are calculated for midday clear sky conditions at Hyytiälä, 1 April.

${ }^{C}$ For 12-h daytime average $\mathrm{OH}$ radical concentration of $5.3^{*} 10^{5}$ molecule $\mathrm{cm}^{-3}$.

$D$ For a monthly average $\mathrm{O}_{3}$ concentration of $9.96^{*} 10^{11}$ molecule $\mathrm{cm}^{-3}$ (41 ppbv).

$E$ For a 12-h nighttime average $\mathrm{NO}_{3}$ concentration of $6.51^{*} 10^{7}$ molecule $\mathrm{cm}^{-3}$. All rate constants are at $298 \pm 5 \mathrm{~K}$. (F=calculated using quantum yields $\Phi=1 / \Phi=0.1$ as estimates)

References from NIST Chemical Kinetics Database:

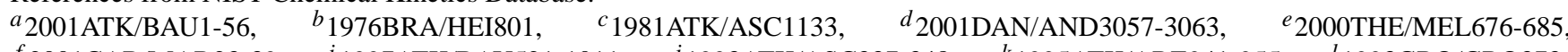
$f_{2001 C A B / M A R 23-39,}{ }^{2}$ 1997ATK/BAU521-1011, $j$ 1993ATK/ASC337-348, ${ }^{k}$ 1995ATK/ARE941-955, $l_{1993 G R O / G R O 373-}$

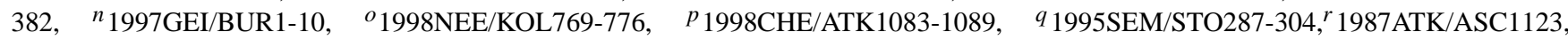
${ }^{s}$ 1992GRO/WIL1395-1405, ${ }^{t} 1998$ GRO/GRO21-29, ${ }^{u} 1991$ ATK459-507.

Other references: ${ }^{g}$ Albaladejo et al. (2002), ${ }^{h}$ Bowman et al. (2003), ${ }^{m}$ Fruekilde et al. (1998), ${ }^{v}$ Finalyson-Pitts and Pitts (2000), ${ }^{w}$ Martinez et al. (1992), ${ }^{x}$ Moortgat (2001), ${ }^{y}$ Tadic et al. (2001), ${ }^{z}$ Mannschreck et al. (2003). ${ }^{B}-{ }^{E}$ Hakola et al. (2003)

the Fig. 3 where on last four days, when air masses where coming from the East, the concentration increases with the temperature. However, long sampling time $(24 \mathrm{~h})$ and small number of samples limit the correlation analysis.

Concentrations of carbonyl compounds in March/April 2003 were significantly higher than aromatic hydrocarbon and monoterpene concentrations measured in Hyytiälä in April 2002 (Fig. 4). In a rural site in Colorado carbonyl concentrations were three times higher than monoterpenes and aromatics (Fehsenfeld et al., 1992). However, in a rural site in Alabama monoterpene concentration was over two times higher than carbonyl concentration.

\subsection{Calculation of reaction/photolysis rates}

Average lifetimes of the measured carbonyls with respect to reactions with $\mathrm{OH}, \mathrm{O}_{3}$ and $\mathrm{NO}_{3}$ were calculated based on oxidant concentration estimations in Hyytiälä by Hakola et al. (2003). Rate constants were obtained mainly from the 


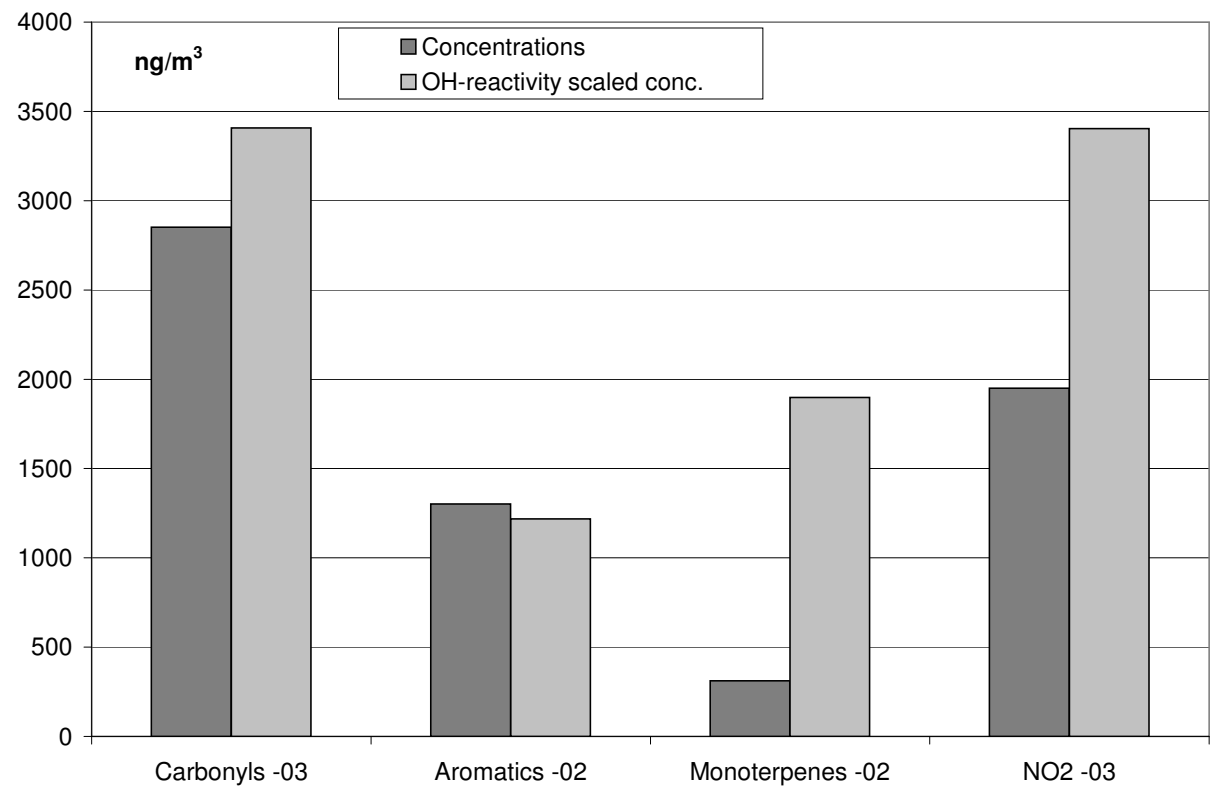

Fig. 4. Average of carbonyl concentrations (24-h samples) measured in March/April 2003, average value of $\mathrm{NO}_{2}$ from March/April 2003 (chemiluminescence analyser) and aromatic hydrocarbon and monoterpene concentrations measured in April 2002 (3-h continuous sampling, 15-29 April) together with OH-reactivity scaled concentrations ( $C_{\text {eqv }}$, as formaldehyde equivalents).

National Institute for Standards and Technology Chemical Kinetics Database (NIST, 2003). Rate constants for reactions of OH-radical with octanal, decanal, undecanal and laurinaldehyde were not found in literature and therefore the reaction rates were estimated using the structure-reactivity relationship described by Kwok and Atkinson (1995). Rate constants for reactions of $\mathrm{OH}$-radical with $\mathrm{C}_{4}-\mathrm{C}_{7}$ aldehydes found in literature are higher than given by the structurereactivity relationship calculations (Table 1).

Photolysis rates were calculated using Eq. (1) (FinlaysonPitts and Pitts, 2000).

$k_{p}\left(s^{-1}\right)=\sum_{\lambda=290 n m}^{\lambda i} \phi_{a v}(\lambda) \sigma_{a v}(\lambda) F_{a v}(\lambda)$,

where $k_{p}$ is the photolysis rate, $\Phi_{a v}$ is the primary quantum yield and represents the fraction of excited molecules that undergo photochemistry averaged over the wavelength interval $\Delta \lambda$, centered at $\lambda, \sigma_{a v}(\lambda)$ is the absorption cross section in base e, averaged over the wavelength interval $\Delta \lambda$, centered at $\lambda$, and $\mathrm{F}_{a v}(\lambda)$ is the actinic flux in photons summed over the wavelength interval $\Delta \lambda$, centered at $\lambda$, at a solar zenith angle $\theta$ corrected for season by correction factor of EarthSun distance D. Solar zenith angle was calculated using the method given in Finlayson-Pitts and Pitts (2000). The calculated midday solar zenith angle was $58^{\circ}$ at Hyytiälä for 1 April. Actinic fluxes used in the all calculations were for clear sky conditions and zenith angle $60^{\circ}$ (Finlayson-Pitts and Pitts, 2000). These actinic fluxes are calculated for surface albedo $(\alpha)$ of 0.05 . In a snow-covered coniferous forest like Hyytiälä, the surface albedo $(\alpha)$ is higher $(\alpha=0.26$ in Betts, 2000) and this leads to higher actinic fluxes and hence enhanced photochemistry. If calculated using the actinic fluxes for surface albedo 0.8 , photolysis rates were 2.5 times higher.

Absorption cross sections and quantum yields for different wavelengths were obtained from literature given in Table 1. For MEK quantum yields $(\Phi)$ for different wavelenghts were not found from literature and therefore values $\Phi=1$ and $\Phi=0.1$ were used for all wavelengths in the estimations. The quantum yield value 1 represents maximum rate of photolysis, but the true rate constant may be much smaller, even zero. The uncertainty in using estimated quantum yields $(\Phi=1$ and $\Phi=0.1)$ of MEK is demonstrated by the variations in $\Phi$ value with wavelength. For acetaldehyde quantum yields varied between 0.02 and 0.52 at wavelengths 290-330 nm and for acetone between 0.01 and 0.11 at wavelengths 302-335 nm (Finlayson-Pitts and Pitts, 2000). Photolysis rate constants for acetone using the quantum yield values from literature and value 0.1 were $2.1^{*} 10^{-6} \mathrm{~s}^{-1}$ and $3.9^{*} 10^{-7} \mathrm{~s}^{-1}$, respectively. Correction factor $(\mathrm{D}=1.001)$ for Earth-Sun distance in April was obtained from FinlaysonPitts and Pitts (2000).

\subsection{Lifetimes of carbonyl compounds in Hyytiälä}

Calculated lifetimes and reaction rates are presented in Table 1. For most of the compounds the main sink reactions in Hyytiälä in spring are reactions with $\mathrm{OH}$ radicals and photolysis. For 6-MHO and limona ketone also reactions with ozone are important. However, more quantum yield and 
absorption cross section measurements are required to verify these conclusions. Some additional estimates of the photolytic lifetimes of carbonyl compounds can be found in the literature. In the study of Moortgat (2001) estimated photolytic lifetimes of nopinone and limona ketone are longer than the lifetime of acetaldehyde. Hence, for these compounds photolysis is not expected to be as important loss process as reactions with $\mathrm{OH}$ radicals and ozone. Photolytic lifetimes of nonanal and 2-butenal were close to the lifetimes of pentanal and butanal (Moortgat, 2001).

The most important reaction for formaldehyde in Hyytiälä in spring is photolysis (photolytic lifetime $8 \mathrm{~h}$ ). Overall lifetimes for 6-MHO and limona ketone due to $\mathrm{OH}$-radical and ozone are very short, $35 \mathrm{~min}$ and $1.3 \mathrm{~h}$, respectively. For larger aldehydes $\left(\mathrm{C}_{4}-\mathrm{C}_{12}\right)$ main reaction is with $\mathrm{OH}$ radicals (average lifetime about $18 \mathrm{~h}$ ), but also photolysis is important (average lifetime for $\mathrm{C}_{4}-\mathrm{C}_{9}$ aldehydes about $1.5 \mathrm{~d}$ ).

Other possible sinks are scavenging by aqueous droplets and dry deposition. Grosjean and Wright (1983) identified up to ten $\mathrm{C}_{1}-\mathrm{C}_{6}$ carbonyls in fog, ice fog, mist, cloud water or rainwater samples and also several unidentified carbonyls were present. Kawamura et al. (2001) studied wet deposition of carbonyls in Los Angeles. They found that wet scavenging is an important loss process for formaldehyde. For the other $\mathrm{C}_{1}-\mathrm{C}_{4}$ aldehydes wet deposition was less significant. Formaldehyde was more efficiently scavenged than acetaldehyde and propanal by a factor of 10 and 30, respectively. The air/rain molar ratios increased with an increase in carbon number of aldehydes. This is in accordance with Henry's Law constants (Zhou and Mopper, 1990). Satsumabayashi et al. (2001) found significant concentrations of pinonaldehyde $(0.16-13 \mu \mathrm{g} / \mathrm{l})$ in rain and snow in central Japan.

Based on model simulations by Zhang et al. (2002), dry deposition is likely to be an important loss process for $\mathrm{C}_{1}$ $\mathrm{C}_{8}$ carbonyls in coniferous forests at temperatures above the temperature at which stomata starts opening. However, there are no measurements available to support this.

\subsection{Importance of the carbonyl compounds as an $\mathrm{OH}$-sink} in Hyytälä

Although the concentrations of the heavier $\mathrm{C}_{5}-\mathrm{C}_{12}$ aldehydes were lower than the light aldehydes, their contribution to local photochemistry is important due to faster reactions with the hydroxyl radical. Figures 1 and 2 show the $\mathrm{OH}$ reactivityscaled concentrations of carbonyl compounds. Based on $\mathrm{OH}$-reactivity, concentrations were scaled to formaldehyde equivalents according to Equation 2.

$C_{e q v}=\frac{\text { Conc } \cdot k_{\mathrm{OH}}}{k_{\mathrm{OH}}(\mathrm{HCHO})}$

$C_{e q v}$ is equivalent concentration of the compound, $C_{\text {onc }}$ measured concentration of the compound, $k_{\mathrm{OH}}$ rate constant of the compound for the reaction with $\mathrm{OH}$-radicals and $k_{\mathrm{OH}}(\mathrm{HCHO})$ rate constant of the formaldehyde for the re- action with OH-radicals. Percent contributions of the different compounds were calculated from reactive-scaled averages of the 24-h concentrations. The contribution of the $\mathrm{C}_{5}-\mathrm{C}_{12}$ aldehydes to the total $\mathrm{OH}$-reactivity of carbonyls was $29 \pm 6 \%$. Also 6-methyl-5-hepten-2-one (6-MHO) is important accounting for $12 \pm 5 \%$ of the carbonyl reactions with OH-radicals.

Figure 4 shows reactivity scaled concentrations of carbonyls, aromatics, monoterpenes and nitrogen dioxide $\left(\mathrm{NO}_{2}\right)$. Concentrations are scaled to formaldehyde equivalents according to Eq. (2). Reaction rate constants for aromatic hydrocarbons and monoterpenes at $298 \pm 5 \mathrm{~K}$ and $1 \mathrm{~atm}$ were obtained from the National Institute for Standards and Technology Chemical Kinetics Database (NIST, 2003). For $\mathrm{NO}_{2}$ effective second order rate constant was obtained from Finlayson-Pitts and Pitts (2000). Total contribution of carbonyls as an $\mathrm{OH}$ sink is comparable to that of $\mathrm{NO}_{2}$ and 2.8 times higher than that of aromatic hydrocarbons and 1.8 times higher than monoterpenes.

\subsection{Sources of carbonyl compounds}

To study source areas of carbonyls and their precursors, 5-day back trajectories were obtained for every 4-h from the NOAA Air Resources Laboratory (ARL) (Draxler and Rolph, 2003 and Rolph, 2003). The trajectories were categorized into different source areas; Arctic, East, Atlantic, and Scandinavia based on where they had travelled longest. Arctic describes the areas with latitude $>71^{\circ}$. East consists mainly of Russia. Atlantic describes the areas in the North Atlantic and Scandinavia consists of Finland and Northern parts of Sweden and Norway. During the measurement period there were no air masses coming from the Central Europe. Highest concentrations of $\mathrm{C}_{1}-\mathrm{C}_{8}$ aldehydes and acetone excluding pentanal were in the continental Eastern air masses (the sum of the all measured carbonyl concentrations was averagely $3670 \mathrm{ng} / \mathrm{m}^{3}$ ), where as the concentrations in marine air masses from Arctic and Atlantic were lower (the sum of the concentrations being averagely 2740 and $2570 \mathrm{ng} / \mathrm{m}^{3}$, respectively). However, lowest concentrations were measured from the air masses cycled long time over the Scandinavia the average concentration sum being $1970 \mathrm{ng} / \mathrm{m}^{3}$. Only two days were categorized into that area. Concentrations in the air masses coming from the direction of the closest town Tampere with 201000 inhabitants and 85000 cars (40 km from Hyytiälä) did not show increased concentrations.

Main source of formaldehyde in this rural forested site is expected to be oxidation of hydrocarbons and other volatile organic compounds. Formaldehyde has also primary sources such as biomass burning and automobile exhaust, but because the lifetime of formaldehyde is relatively short (in the order of hours, see Table 1), it is not transported far from the emission sources during daytime. Concentrations of mainly anthropogenic hydrocarbons e.g. aromatic 
Table 2. Detection limits and minimum, maximum, average and median values of the 24-hour concentrations of the carbonyl compounds measured in the ambient air at Hyytiälä, 19 March - 13 April 2003 and average concentrations of the 24-hour samples in the ambient air of the city of Helsinki in February (average of 8 samples) and May (average of 4 samples) 2004.

\begin{tabular}{|c|c|c|c|c|c|c|c|}
\hline $\mathrm{ng} / \mathrm{m}^{3}$ & Det limit & Minimum & Maximum & Average & Median & Helsinki Feb -04 & Helsinki May -04 \\
\hline Formaldehyde & 19 & 220 & 785 & 478 & 479 & 297 & 1304 \\
\hline Acetaldehyde & 41 & 183 & 539 & 357 & 385 & 133 & 493 \\
\hline Propanal & 15 & 41 & 150 & 80 & 75 & 61 & 82 \\
\hline Butanal & 9 & 24 & 82 & 57 & 55 & 69 & 57 \\
\hline Pentanal & 10 & $<\mathrm{DL}$ & 88 & 46 & 48 & 67 & 52 \\
\hline Hexanal & 8 & 27 & 96 & 48 & 45 & 35 & 64 \\
\hline Heptanal & 28 & $<\mathrm{DL}$ & 51 & $<\mathrm{DL}$ & $<\mathrm{DL}$ & 23 & 49 \\
\hline Octanal & 37 & $<\mathrm{DL}$ & 187 & 82 & 73 & 47 & 297 \\
\hline Nonanal & 131 & $<\mathrm{DL}$ & $<\mathrm{DL}$ & $<\mathrm{DL}$ & $<\mathrm{DL}$ & 123 & 204 \\
\hline Decanal & 14 & 24 & 218 & 88 & 70 & 133 & 301 \\
\hline Undecanal & 4 & $<\mathrm{DL}$ & 10 & $<\mathrm{DL}$ & $<\mathrm{DL}$ & 15 & 23 \\
\hline Laurinaldehyde & 1 & $<\mathrm{DL}$ & 9 & 4 & 2 & 10 & 3 \\
\hline MEK & 135 & $<\mathrm{DL}$ & 441 & 215 & 180 & 51 & $<\mathrm{DL}$ \\
\hline Acetone & 132 & 689 & 2095 & 1339 & 1186 & 865 & 1563 \\
\hline Nopinone & 5 & $<\mathrm{DL}$ & 29 & 9 & 6 & 19 & 16 \\
\hline trans-2-hexenal & 3 & $<\mathrm{DL}$ & $<\mathrm{DL}$ & $<\mathrm{DL}$ & $<\mathrm{DL}$ & 0 & 0 \\
\hline Limona ketone & 3 & $<\mathrm{DL}$ & 39 & 5 & $>\mathrm{DL}$ & 0 & 6 \\
\hline 6-MHO & 2 & $>\mathrm{DL}$ & 36 & 21 & 14 & 10 & 17 \\
\hline Methacrolein & 7 & $<\mathrm{DL}$ & $<\mathrm{DL}$ & $<\mathrm{DL}$ & $<\mathrm{DL}$ & 20 & 17 \\
\hline Benzaldehyde & 5 & 11 & 40 & 22 & 21 & 69 & 26 \\
\hline 2-butenal & 7 & $<\mathrm{DL}$ & $<\mathrm{DL}$ & $<\mathrm{DL}$ & $<\mathrm{DL}$ & $<\mathrm{DL}$ & $<\mathrm{DL}$ \\
\hline m-Tolualdehyde & 4 & $<\mathrm{DL}$ & 7 & $<\mathrm{DL}$ & $<\mathrm{DL}$ & $<\mathrm{DL}$ & $<\mathrm{DL}$ \\
\hline Acrolein & 9 & $<\mathrm{DL}$ & $<\mathrm{DL}$ & $<\mathrm{DL}$ & $<\mathrm{DL}$ & $<\mathrm{DL}$ & $<\mathrm{DL}$ \\
\hline SUM & & 1756 & 4711 & 2851 & 2669 & 2046 & 4573 \\
\hline
\end{tabular}

hydrocarbons in Hyytiälä are much lower than in the city of Helsinki (largest urban area in Finland with 950000 inhabitants) (Hellén et al., 2002). As an example concentrations of 1,2,3-trimethylbenzene and 1,2,4-trimethylbenzene were almost 10 times higher in Helsinki than in Hyytiälä during winter 2000. However, concentrations of carbonyls in Hyytiälä in March/April 2003 were at same level as in Helsinki in February and May 2004 (Table 2). The main reaction of trimethylbenzene is a reaction with OH-radical (Atkinson, 2000) with lifetime of about 16 hours (March/April, Hyytiälä). This lifetime is at the same level or longer than overall lifetime of most aldehydes. If the main sources of carbonyls in Hyytiälä would be the same anthropogenic sources (e.g. traffic) as for the aromatic hydrocarbons also their concentrations would have decreased as much as or even more than concentrations of the aromatic compounds. Therefore the direct anthropogenic sources do not explain the concentrations of these aldehydes in Hyytiälä. In global estimates of formaldehyde emissions biomass burning and automobile exhausts are much less important than hydrocarbon oxidation (Singh et al., 2000). Emissions from automobile exhaust and biomass burning comprise $5 \%$ of the formaldehyde produced from methane oxidation.
In our dataset formaldehyde shows highest positive linear correlation with propanal $\left(\mathrm{R}^{2}=0.64\right)$, acetaldehyde $\left(\mathrm{R}^{2}=0.63\right)$ and butanal $\left(\mathrm{R}^{2}=0.55\right)$. The main source of these light carbonyls in Hyytiälä is probably the oxidation of higher hydrocarbons. Acetaldehyde, propanal and butanal have all been detected in automobile exhausts and in wood combustion emissions (Schauer et al., 2002 and McDonald et al., 2000). In a global emission estimate by Singh et al. (2003), main sources of acetaldehyde and propanal are oceanic. Transport of marine air is not expected to be an important source in Hyytiälä. Trajectory analysis showed that highest concentrations were in continental air masses coming from the East. In addition to oceanic sources, oxidation of hydrocarbons and primary biogenic emissions are globally more significant than primary anthropogenic sources. However, very little is known about the sources of butanal, propanal and acetaldehyde and the estimation by Singh et al. (2003) is a first highly uncertain estimate.

Similar to formaldehyde, acetone shows highest positive correlation with propanal $\left(\mathrm{R}^{2}=0.66\right)$ and acetaldehyde $\left(\mathrm{R}^{2}=0.56\right)$. According to emission inventories, the main sources of acetone are primary biogenic emissions and oxidation of anthropogenic and biogenic VOCs (Singh et al., 2000). Other important sources are decaying plant matter, 
biomass burning and direct anthropogenic sources. Trees can be an important source of acetone in Hyytiälä. Janson and Serves (2001) found high concentrations of acetone in branch emission measurements of Scots pine and Norway spruce conducted in Hyytiälä in March/April in 1999. Oxidation of monoterpenes is an important secondary source of acetone. High acetone yields were measured in reactions of monoterpenes with $\mathrm{OH}$ radicals and $\mathrm{O}_{3}$ (Reissell et al., 1999). In spite of the cold season, emissions of monoterpenes have been detected in enclosure measurement of Scots pine and Norway spruce during March and April (Hakola et al., 2003, Janson and Serves, 2001). Due to the long lifetime, acetone can be transported long distances. Concentration of acetone in Hyytiälä is at the same level as in the city of Helsinki (Table 2).

Nopinone shows positive linear correlation with decanal $\left(\mathrm{R}^{2}=0.56\right)$. Nopinone is a reaction product of the biogenic hydrocarbon $\beta$-pinene (Hakola et al., 1994). Ozonolysis of plant lipids, either on leaf surfaces or on atmospheric particulate matter, can be an important source of long-chain aldehydes in forest environments (Bowman et al., 2003). A source for nonanal can be ozonolysis of oleic acid, which is biologically produced and ubiquitously present in the biosphere (Yokouchi et al., 1990). However, in our study nonanal remained below the detection limit $\left(131 \mathrm{ng} / \mathrm{m}^{3}\right)$. It is possible that some of decanal and octanal in the air of Hyytiälä is emitted directly from the trees. Small emissions of decanal, octanal and other heavier $\mathrm{C}_{6}-\mathrm{C}_{12}$ aldehydes have been detected in enclosure measurements of orange leaves (Possanzini et al., 2000) and oaks (König et al., 1995). Automobile exhausts and wood combustion are known anthropogenic sources of these high molecular weight aldehydes (Schauer et al., 2002 and McDonald et al., 2000). Lifetimes of $\mathrm{C}_{6}-\mathrm{C}_{12}$ aldehydes are short (in the order of hours, see Table 1) and they are most probably not transported far from source areas. Also hexanal and heptanal are mentioned in a study by Bowman et al. (2003), where it is suggested that long-chain aldehydes are produced from ozonolysis of plant lipids, and in enclosure measurements of various plants by Possazzini et al. (2000) and König et al. (1995). In this study hexanal and heptanal do not correlate with other long-chain aldehydes. Hexanal shows highest linear relationship with butanal $\left(\mathrm{R}^{2}=0.53\right)$, which is more connected to formaldehyde and other small carbonyls. Heptanal concentrations remained below the detection limit $\left(28 \mathrm{ng} / \mathrm{m}^{3}\right)$ during most of the days.

The lifetime of methyl ethyl ketone (MEK) is longer than the lifetime of other carbonyls, excluding acetone (Table 1). MEK does not show positive correlation with most of the compounds. Highest correlation is with acetone $\left(\mathrm{R}^{2}=0.38\right)$. Because of the longer lifetime (several days), MEK can be transported much longer distances than the other measured carbonyls. Known anthropogenic sources of MEK are automobile exhaust and wood combustion (Schauer et al., 2002 and McDonald et al., 2000). MEK is also used as solvent
(Friedrich and Obermeier, 1999). In the emission inventory by Singh et al. (2003) it is concluded that primary anthropogenic emissions are insignificant as a global source of MEK compared to primary biogenic sources, biomass burning and oxidation of anthropogenic hydrocarbons, but data for quantitative estimations of the magnitude of these emissions are not available.

6-methyl-5-hepten-2-one (6-MHO) did not show positive correlation with any other carbonyls $\left(\mathrm{R}^{2}<0.10\right)$. Ozonolysis of linalool can lead to formation of 6-MHO (Shu et al., 1997) but this does not explain the relatively high concentrations of 6-MHO observed in Hyytiälä. Linalool has not been detected in ambient air or in the emissions of Scots pine at Hyytiälä in the early spring (Tarvainen et al., 2004). Fruekilde et al. (1998) have found that the ozonolysis of epicuticular wax from leaves of deciduous trees is a possible source for 6MHO in ambient air.

\section{Conclusions}

A variety of carbonyl compounds were quantified in air inside a boreal coniferous forest. The most abundant carbonyls were acetone, formaldehyde and acetaldehyde. Because of low monoterpene concentrations in early spring, concentrations of reaction products nopinone and limona ketone were also low compared to the most abundant carbonyls.

Concentration of carbonyl compounds in Hyytiälä in March/April 2003 was much higher than the concentration of aromatic hydrocarbons and monoterpenes in April 2002 and therefore the contribution of the carbonyls to the total mass of volatile organic compounds is significant at this rural forested site.

Main sink reactions for most of the carbonyl compounds in Hyytiälä in springtime are expected to be reactions with the $\mathrm{OH}$ radical and photolysis. For 6-MHO and limona ketone also reactions with ozone are important.

Scaling the concentrations against reactivity with the $\mathrm{OH}-$ radical showed, that in spite of relatively low ambient concentrations higher molecular weight aldehydes contribute significantly to the total $\mathrm{OH}$-reactive mass of carbonyls. The impact of carbonyl compounds on OH-radical chemistry is important. Contribution of carbonyls as an $\mathrm{OH}$ sink is comparable to that of $\mathrm{NO}_{2}$ and higher than monoterpenes and aromatic hydrocarbons.

The sources of carbonyl compounds are presently highly uncertain. Because of the relatively short lifetimes of aldehydes and ketones, secondary production from the oxidation of other organic compounds and primary biogenic sources are expected to dominate in Hyytiälä. Some small local anthropogenic sources (wood combustion or traffic) may also exist, but they are negligible in this large forested area. Based on trajectory analysis highest concentrations of carbonyl compounds were in the air masses coming from the Eastern continental areas. 
Acknowledgements. H. Hellén thanks the Maj and Tor Nessling Foundation for financial support. The authors gratefully acknowledge the NOAA Air Resources Laboratory (ARL) for the provision of the HYSPLIT transport and dispersion model and/or READY website (http://www.arl.noaa.gov/ready.html) used in this publication. We thank P. Keronen for kindly providing the $\mathrm{NO}_{2}$ data.

Edited by: A. Laaksonen

\section{References}

Albaladejo, J., Ballesteros, B., Jiménez, E., Martín, P., and Martínez, E.: A PLP-LIF kinetic study of the atmospheric reactivity of a series of $\mathrm{C}_{4}-\mathrm{C}_{7}$ saturated and unsaturated aliphatic aldehydes with OH, Atmos. Envir., 36, 3231-3139, 2002.

Arey, J., Winer, A. M., Atkinson, R., Aschmann, S. M., Long, W. D., and Morrison, C. L.: The emission of (Z)-3-hexen-1-ol, (Z)3-hexenylacetate and other oxygenated hydrocarbons from agricultural plant species, Atmos. Envir., 25A, 1063-1075, 1991.

Atkinson, R.: Atmospheric chemistry of VOCs and $\mathrm{NO}_{\mathrm{x}}$, Atmos. Envir., 34, 2063-2101, 2000.

Betts, R. A.: Offset of the potential carbon sink from boreal forestation by decreases in surface albedo, Nature, 408, 187-190, 2000.

Bowman, J. H., Barket Jr., D. J., and Shepson, P. B.: Atmospheric chemistry of nonanal, Env. Sci. Tec., 37, 2218-2225, 2003.

Ciccioli, P., Brancaleoni, E., Frattoni, M., Cecinato, A., and Brachetti, A.: Ubiquitous occurrence of semi-volatile carbonyl compounds in tropospheric samples and their possible sources, Atmos. Envir., 27A, 1891-1901, 1993.

Draxler, R. R. and Rolph, G. D.: HYSPLIT (HYbrid Single-Particle Lagrangian Integrated Trajectory) Model access via NOAA ARL READY Website (http://www.arl.noaa.gov/ready/hysplit4.html), NOAA Air Resources Laboratory, Silver Spring, MD, 2003.

EMEP: Manual for sampling and chemical analysis, Norwegian Institute for Air Research, EMEP/CCC-Report 1/95, O-7726, 1996.

Fall, R.: Biogenic emissions of volatile organic compounds from higher plants, in: Reactive Hydrocarbons in the Atmosphere, edited by Hewitt, C. N., Academic Press, London, 41-96, 1999.

Fehsenfeld, F., Calvert, J., Fall, R., Goldan, P., Guenther, A. B., Hewitt, C. N., Lamb, B., Liu, S., Trainer, M., Westberg, H., and Zimmerman, P.: Emissions of Volatile Organic Compounds from Vegetation and the Implications for Atmospheric Chemistry, Global Biog., 6, 389-430, 1992.

Finlayson-Pitts, B. J. and Pitts, J. N.: Chemistry of the upper and lower atmosphere, Academic Press, San Diego, 2000.

Friedrich, R. and Obermeier, A.: Anthropogenic Emissions of volatile organic compounds, in: Reactive Hydrocarbons in the Atmosphere, edited by Hewitt, C. N., Academic Press, London, 1-39, 1999.

Fruekilde, P., Hjorth, J., Jensen, N. R., Kotzias, D., and Larsen, B.: Ozonolysis at vegetation surfaces: a source of acetone, 4oxopentanal, 6-methyl-5-hepten-2-one and geranyl acetone in the troposphere, Atmos. Envir., 32, 1893-1902, 1998.

Grosjean, D. and Wright, B.: Carbonyls in urban fog, ice fog, cloud water and rainwater, Atmos. Envir., 17, 2093-2096, 1983.

Grosjean, E., Grosjean, D., Fraser, M. P., and Cass, G. R.: Air quality model evaluation data for organics. $2 . \mathrm{C}_{1}-\mathrm{C}_{14}$ carbonyls in
Los Angeles, Env. Sci. Tec., 30, 2687-5703, 1996.

Grosjean, E., Green, P. G., and Grosjean, D.: Liquid Chromatography Analysis of Carbonyl (2,4-Dinitrophenyl)hydrazones with Detection by Diode Array Ultroviolet Spectroscopy and by Atmospheric Pressure Negative Chemical Ionization Mass Spectometry, Analyt. Chem., 71, 1851-1861, 1999.

Grosjean, D., Grosjean, E., and Moreira, L. F. R.: Speciated ambient carbonyls in Rio de Janeiro, Brazil. Env. Sci. Tec., 36, 13891395, 2002.

Hakola, H., Arey, J., Aschmann, S. M., and Atkinson, R.: Product formation from gas-phase reactions of $\mathrm{OH}$ radicals and $\mathrm{O}_{3}$ with series of monoterpenes, J. Atmos. Chem., 18, 75-102, 1994.

Hakola, H., Laurila, T., Lindfors, V., Hellén, H., Gaman, A., and Rinne, J.: Variation of the VOC emission rates of birch species during the growing season, Boreal Environment Research, 6, 237-249, 2001.

Hakola, H., Tarvainen, V., Laurila, T., Hiltunen, V., Hellén, H., and Keronen, P.: Seasonal variation of VOC concentrations above a boreal coniferous forest, Atmos. Envir., 37, 1623-1634, 2003.

Hellén, H., Hakola, H., Laurila T., Hiltunen, V., and Koskentalo, T.: Aromatic hydrocarbon and methyl tert-butyl ether measurements in ambient air of Helsinki (Finland) using diffusive sampling, Sci. Tot. Env., 298, 55-64, 2002.

Janson, R. and De Serves, C.: Acetone and monoterpene emissions from the boreal forest in northern Europe, Atmos. Envir., 35, 4629-4637, 2001.

Kawamura, K., Steinberg, S., Ng, L. and Kaplan, I. R.: Wet deposition of low molecular weight mono- and di-carboxylic acids, aldehydes and inorganic species in log Angeles, Atmos. Envir., 35, 3917-3926, 2001.

Kwok, E. S. C. and Atkinson, R.: Estimation of hydroxyl radical reaction rate constants for gas-phase organic compounds using a structure-reactivity relationship: an update, Atmos. Envir., 29, 1685-1695, 1995.

König, G., Brunda, M., Puxbaum, H., Hewitt, C. N., Duckham, S. C., and Rudolph, J.: Relative contribution of oxygenated hydrocarbons to the total biogenic VOC emissions of selected MidEuropean agricultural and natural plant species, Atmos. Envir., 29, 861-874, 1995.

Mannschreck, K., Bächmann, K., Barnes, I., Becker, K. H., Heil, Th., Kurtenbach, R., Memmesheimer, M., Mohnen, V., Schmitz, Th., Steinbrecher, R., Obermeier, A., Poppe, D., Volz-Thomas, A., and Zabel, F.: VOC database, Bergishe Universitet Wuppertal, Physical Chemistry, http://www.physchem.uni-wuppertal.de/ PC-WWW_Site/VOC-Database/index.html, 2003.

Martinez, R. D., Buitrago, A. A., Howell, N. W., Hearn, C. H., and Joens, J. A.: The near U.V. spectra of several aliphatic aldehydes and ketones at $300 \mathrm{~K}$, Atmos. Envir., 26A, 785-792, 1992.

Matsunaga, S., Mochida, M., and Kawamura, K.: Variation on the atmospheric concentrations of biogenic carbonyl compounds and their removal processes in the northern forest at Moshiri, Hokkaido Island in Japan, J. Geophys. Res-A., 109, D4, D04302, doi:10.1029/2003JD004100, 2004.

McDonald, J. D., Zielinska, B., Fujita, E. M., Sagebiel, J. C., Chow, J. C., and Watson, J. G.: Fine particle and gaseous emission rates from residential wood combustion, Env. Sci. Tec., 24, 20802091, 2000.

Moortgat, G. K.: Important photochemical processes in the atmosphere, Pur. A. Chem., 73, 487-490, 2001. 
NIST Chemical Kinetics Database: Chemical Kinetics Database on the Web, Public Beta Release 1.1, Standard Reference Database 17, Version 7.0 (Web Version), National Institute of Standards and Technology, http://kinetics.nist.gov/index.php/, 2003.

Possanzini, M., Di Palo, V., and Cecinato, A.: Sources and photodecomposition of formaldehyde and acetaldehyde in Rome ambient air, Atmos. Envir., 36, 3195-3201, 2002.

Possanzini, M., Di Palo, V., Brancaleoni, E., Frattoni, M., and Ciccioli, P.: A train of carbon and DNPH-coated cartridges for the determination of carbonyls from $\mathrm{C}_{1}-\mathrm{C}_{12}$ in air and emission samples, Atmos. Envir., 34, 5311-5318, 2000.

Reissell, A., Harry, C., Ascchmann, S. M., Atkinson, R., and Arey, J.: Formation of acetone from the $\mathrm{OH}$ radical- and $\mathrm{O}_{3}$ initiated reactions of a series of monoterpenes, J. Geo. Res-A., 109, 13 869-13 879, 1999.

Rolph, G. D.: Real-time Environmental Applications and Display System (READY) Website (http://www.arl.noaa.gov/ready/ hysplit4.html), NOAA Air Resources Laboratory, Silver Spring, MD, 2003.

Satsumabayashi, H., Nishizawa, H., Yokouchi, Y., and Ueda, H.: Pinonaldehyde and some other organics in rain and snow in central Japan, Chemosphere, 45, 887-891, 2001.

Schauer, J. J., Kleeman, M. J., Cass, G. R., and Simoneit, B. R. T.: Measurement of emissions from air pollution sources, 5. $C_{1}-C_{32}$ organic compounds from gasoline powered motor vehicles, Env. Sci. Tec., 36, 1169-1180, 2002.

Singh, H., Chen, Y., Tabazadeh, A., Fukui, Y., Bey, I., Yantosca, R., Jakob, D., Arnold, F., Wohlfrom, K., Atlas, E., Flocke, F., Blake, D., Heikes, B., Snow, J., Talbot, R., Gregory, G., Sachse, G., Vay, S., and Kondo, Y.: Distribution and fate of selected oxygenated organic species in the troposphere and lower stratosphere over Atlantic, J. Geo. Res-A., 105, D3, 3795-3805, 2000.

Singh, H. B., Salas, L. J., Chatfield, R. B., Czech, E., Fried, A., Walega, J., Evans, M. J., Fiel, B. D., Jacob, J., Blake, D., Heikes, B., Talbot, R., Sachse, G., Crawford, J. H., Avery, M. A., Sandholm, S., and Fuelberg, H.: Analysis of the atmospheric distribution, sources, and sinks of oxygenated volatile organic chemicals (OVOC) based on measurements over the Pacific during TRACE-P, J. Geophys. Res., 109, D15S07, doi:10.1029/2003JD003883, 2004.
Solberg, S., Dye, C., and Schmidbauer, N.: Carbonyls and nonmethane hydrocarbons at rural European sites from the Mediterranean to the Arctic, J. Atmos. Chem., 25, 33-66, 1996.

Tadic, J., Juranic, I., and Moortgat, G. K.: Pressure dependence of the photooxidation of selected carbonyl compounds in air: nbutanal and n-pentanal, J. Photoch. A., 143, 169-179, 2001.

Tarvainen, V., Hakola, H., Reissell, A., Hellén, H., Thum, T., Laurila, T., Ruuskanen, T., Bäck, J., Juurola, E., Hari, P., and Kulmala, M.: Seasonal development of VOC emissions from pinus sylvestris. Submitted to Atmospheric chemisty and physics, 2004.

Vesala, T., Haataja, J., Aalto, P., Altimir, N., Buzorius, G., Garam, E., Hämeri, K., Ilvesniemi, H., Jokinen, V., Keronen, P., Lahti, T., Markkanen, T., Mäkelä, J. M., Nikinmaa, E., Palmroth, S., Palva, L., Pohja, T., Pumpanen, J., Rannik, Ü., Siivola, E., Ylitalo, H., Hari, P., and Kulmala, M.: Long-term field measurements of atmosphere-surface interactions in boreal forest combining forest ecology, micrometeorology, aerosol physics and atmospheric chemistry, Trends in Heat, Mass \& Momentum Transfer 4, 1735, 1998.

Yokouchi, Y., Mukai, H., Nakajima, K., and Ambe, Y.: Semivolatile aldehydes as predominant organic gases in remote areas, Atmos. Envir., 24A, 439-442, 1990.

Zang, L., Moran, M. D., Makar, P. A., Brook, J. R., and Gong, S.: Modelling gaseous dry deposition in AURAMS: a unified regional air-quality modelling system, Atmos. Envir., 36, 537560, 2002.

Zhou, X. and Mopper, K.: Apparent partition coefficients of 15 carbonyl compounds between air and seawater nad between air and freshwater; implications for air-sea exchange, Env. Sci. Tec., 24, 1864-1869, 1990. 